\title{
A note on the effect of diet and type of fat on cellulose degradability in the rumen of sheep
}

\author{
M. Szumacher-Strabel, A. Cieślak and A. Potkański \\ Department of Animal Nutrition and Feed Management, \\ August Cieszkowski Agricultural University \\ Wolynska 33, 60-637 Poznań, Poland
}

(Received 20 September 1999; accepted 15 July 2000)

\section{ABSTRACT}

The effect of diet type and fat addition on cellulose degradability was estimated on four rams fitted with rumen cannulas in a $4 \times 4$ Latin square design experiment. The animals were fed diets composed of $100 \%$ meadow hay ( $l^{\text {st }}$ trial) or $40 \%$ meadow hay and $60 \%$ concentrate ( $2^{\text {ns }}$ trial). Diets were supplemented with $0,4,8$ or $10 \%$ rape seed oil, linseed oil or tallow. There were three experiments in each trial. Effective degradability of cellulose may vary among different fat sources and type of diet. Adding rape seed oil decreased effective degradability and when the animals were given meadow hay ( $1^{\mathrm{si}}$ trial), differences were significant $(\mathrm{P} \leq 0.05)$. A decrease was observed in effective degradability when linseed oil was added to meadow hay $\left(1^{\text {st }}\right.$ trial), but the differences were not significant, whereas linseed oil added to concentrate-hay rations $\left(2^{\text {nd }}\right.$ trial $)$ significantly $(P \leq 0.05)$ increased effective degradability. Adding tallow had no effect on effective cellulose degradability in the rumen of sheep.

KEY WORDS: rumen, fat, cellulose degradability, in sacco, sheep

\section{INTRODUCTION}

High producing ruminants require additional energy in the diet from supplementary sources. Traditional sources of energy like high starch diets result in rapid fermentation in the rumen, decreased $\mathrm{pH}$, which may inhibit forage-digesting bacteria (Garnsworthy, 1997). Inclusion of fat in ruminant diets increases energy density without depressing dry matter intake, however, high levels of fat can reduce fibre digestibility (Honing van der and Tamminga, 1986; Tackett et al., 1996). Kowalczyk et al. (1977) maintain that lipids inhibit growth of cellulolytic bacteria, reducing fibre digestibility. According to Holter et al. (1993) unsaturated fats, rape 
seed or linseed oil, can have a detrimental effect on ruminal microbiota particularly cellulolytic ones, while saturated fats like tallow have a minimal effect on rumen bacteria.

The present study was undertaken to determine the influence of different types of fat given to sheep fed hay or hay-concentrate diet, on cellulose degradability in the rumen.

\section{MATERIAL AND METHODS}

Animal, feed and feeding

Four rumen-cannulated rams (mean body weight $50 \pm 3 \mathrm{~kg}$ ) were fed four diets in a $4 \times 4$ Latin square design in 16-d periods. The first 14 days were used for adaptation to the diet, the last two days for sample collection. Six experiments were carried out in two trials, three experiments in each trial. In the first trial diets were formulated on the basis of $100 \%$ meadow hay chopped into $5 \mathrm{~cm}$ length pieces, in the second, diets were formulated on the basis of $40 \%$ meadow hay and $60 \%$ concentrate. In both trials feeds were supplemented with $0,4,8$ and $10 \%$ of rape seed oil (RSO), linseed oil (LSO) and tallow (TAL) in dry matter. The daily ration was divided into two equal portions and fed at 08.00 and 16.00. The energy value of the rations was $5.31 \mathrm{MJ} \mathrm{NE} / \mathrm{kg}$, whereas the crude protein content was $144 \mathrm{~g}$ per $\mathrm{kg}$. Water was available ad libitum throughout the experiments.

Estimation of rate of degradation of cellulose in sacco

Nylon bag incubations in the rumen started on day 15 . The pore size of bags was $46 \mu \mathrm{m}$. Bags contained approximately $1 \mathrm{~g}$ cellulose. Samples were incubated for $0,2,4,6,8,10,12,16,24$ and $48 \mathrm{~h}$. After withdrawal from the rumen, bags were washed with running tap water and stored at $-18^{\circ} \mathrm{C}$. Degradation data were fitted in two mathematical models (Stensig et al., 1994).

Model of Ørskov and McDonald (1979) (1):

$$
\mathrm{Y}(\mathrm{t})=\mathrm{a}+\mathrm{b}\left(1-\mathrm{e}^{-\mathrm{ct}}\right)
$$

and the revised model of McDonald (1981) (2):

$$
\begin{array}{ll}
Y(t)=a & \text { for } t \leq t_{0} \\
Y(t)=a+b\left(1-e^{-c(t-10)}\right) & \text { for } t>t_{0}
\end{array}
$$

where

$Y(t)$ - the degraded part at time $t$

$\mathrm{a}-$ the intercept with the $\mathrm{Y}$-axis 
$\mathrm{b}$ - the insoluble but potentially degradable fraction

$\mathrm{c}$ - the degradation rate constant $\left(\mathrm{h}^{-1}\right)$

$\mathrm{t}$ - the incubation time $(\mathrm{h})$

$\mathrm{t}_{\mathrm{o}}$ - the lag time (h)

Effective degradability (ED) was calculated according the equation given by Ørskov and McDonald (1979):

$$
\mathrm{ED}=\mathrm{a}+\frac{\mathrm{bc}}{\mathrm{c}+\mathrm{k}}
$$

where a, b, c values come from model (2) and $\mathrm{k}$ is the fractional rate of passage.

\section{Statistical analysis}

The results were subjected to statistical analysis of variance using the SAS software program (User's Guide, 1990).

\section{RESULTS AND DISCUSSION}

The ability to predict animal performance on diets containing different quality of roughages by using simple, reliable and cheap techniques is becoming important in animal nutrition (Khazaal et al., 1993). In our experiments to determine effective degradability of cellulose in sheep we used the in sacco method, which is more suitable than in vitro methods because rumen micro-organisms need time to adapt to new conditions, and in vitro methods therefore tend to underestimate microbial degradation at short incubation times (Stensig et al., 1994; Noziere and Michalet-Doreau, 1996). The results obtained from our experiments indicate that effective degradability (ED) may vary among different fat sources and type of diet (Tables 1 and 2). More important than the quantity of fatty acids in the diet is their type, since long-chain unsaturated fatty acids have a detergent effect on bacterial cell walls (Garnsworthy, 1997). Khorasani et al. (1991) reported that a high concentration of fat containing polyunsaturated fatty acids inhibits growth of microorganisms and fibre digestibility. Also Tackett et al. (1996) found that unprotected fat may cause disturbances in ruminal fermentation that lead to reduced fibre digestibility. Palmquist (1984) suggests that the negative influence of fat on digestibility is less conspicuous if the dietary fibre intake is high. In our experiments, adding RSO decreased the ED degradability in all diets. In the first experiment, where the animals were given meadow hay, the differences were statistically significant $(\mathrm{P} \leq 0.05)$. A decrease was observed in ED when linseed oil (LSO) was 
TABLE 1

Cellulose effective degradability (ED) in the rumen of sheep fed diet composed of $100 \%$ meadow liay

\begin{tabular}{lccccc}
\hline & \multicolumn{4}{c}{ Diet } \\
\cline { 2 - 5 } & I & II & III & IV \\
\hline RSO & $47.3^{\circ} \pm 7.1$ & $42.7^{\mathrm{h}} \pm 6.9$ & $33.5^{\mathrm{a}} \pm 5.4$ & $33.5^{\mathrm{h}} \pm 4.9$ \\
LSO & $54.2^{\circ} \pm 10.2$ & $44.1^{\mathrm{a}} \pm 7.0$ & $45.2^{\mathrm{a}} \pm 6.8$ & $49.8^{\mathrm{h}} \pm 9.3$ \\
TAL & $44.2^{2} \pm 7.0$ & $48.8^{\circ} \pm 9.0$ & $48.7 \pm 9.2$ & $40.2^{2} \pm 5.7$ \\
\hline
\end{tabular}

a. h, c $-\mathrm{P} \leq 0.05$

TABLE 2

Cellulose effective degradability (ED) in the rumen of sheep fed diet composed of $40 \%$ meadow hay and $60 \%$ concentrate

\begin{tabular}{|c|c|c|c|c|}
\hline & \multicolumn{4}{|c|}{ Diet } \\
\hline & I & II & III & IV \\
\hline RSO & $37.7 \pm 10.2$ & $38.9 \pm 10.1$ & $34.4 \pm 5.0$ & $36.4 \pm 9.4$ \\
\hline LSO & $46.1^{\prime \prime} \pm 8.0$ & $50.3^{\mathrm{h}} \pm 9.0$ & $48.0^{4} \pm 9.3$ & $60.3^{\circ} \pm 11.0$ \\
\hline TAL & $44.2 \pm 7.6$ & $43.3 \pm 7.0$ & $45.1 \pm 6.7$ & $43.4 \pm 6.8$ \\
\hline
\end{tabular}

il. h.L $-\mathrm{P} \leq 0.05$

added to meadow hay, but the differences were not significant. According to Ben Salem et al. (1993) negative effects of lipids on rumen digestion were less important when fibre intake was high, whereas addition of LSO to concentrate-hay rations increased ED from 46.19 in a control diet to $50.30,48.01$ and 60.10 , respectively in the $2^{\text {nd }}, 3^{\text {rd }}$ and $4^{\text {th }}$ diets; the differences were significant $(\mathrm{P} \leq 0.05)$.

Addition of fat rich in saturated fatty acids has a less detrimental effect on cellulose degradability. In our experiments addition of TAL had no effect on ED in the rumen of sheep. Also according to Weigel et al. (1997) tallow, which contains mostly saturated fatty acids, can be fed without affecting ruminal fermentation and nutrient digestibility.

\section{REFERENCES}

Ben Salem H., Kr7emiński R., Ferlay A., Doreau M., 1993. Effect of lipid supply on in vivo digestion in cows: comparison of hay and silage diets. Can. J. Anim. Sci. 73, 547-557

Garnsworthy P.C., 1997. Recent Advances in Animal Nutrition. Nottingham University Press, Nottingham, pp. 87-104

Holter J.B., Hayes H.H., Kierstead N., Whitchouse J., 1993. Protein-fat bypass supplement for lactating dairy cows. J. Dairy Sci. 76, 1342-1352 
Honing van der Y., Tamminga S., 1986. Effect of fat on rumen fermentation and gastrointestinal absorption. A seminar in the EC Programme of Coordination of Agricultural Research. National Institute of Animal Science, Forsogsanlag, Foulum (Denmark), pp. 55-69

Khazaal K., Dentinho M.T., Ribeiro J.M., Ørskov E.R., 1993. A comparison of gas production during incubation with rumen contents in vitro and nylon bag degradability as predictors of the apparent digestibility in vivo and the voluntary intake of hays. Anim. Prod. 57, 105-112

Khorasani G.R., Robinson P.H., de Boer G., Kennelly J.J., 1991. Influence of canola fat on yield, fat percentage, fatty acid profile and nitrogen fractions in Holstein milk. J. Dairy Sci. 74, 19041911

Kowalczyk J., Ørskov E.R., Robinson J.J., Stewart C.S., 1977. Effect of fat supplementation on voluntary food intake and rumen metabolism in sheep. Brit. J. Nutr. 37, 251-257

McDonald I., 1981. A revised model for the estimation of protein degradability in the rumen. J. Agr. Sci. 96. 251-252

Noziere P.. Michalet-Doreau B., 1996. Validation of in sacco method - influence of sampling site, nylon bag or rumen contents, on fibrolytic activity of solid-associated microorganisms. Anim. Fecd Sci. Tech. 57, 203-210

$\emptyset$ rskov E.R., McDonald I., 1979. The estimation of protein degradability in the rumen from incubation measurements weighed according to the rate of passage. J. Agr. Sci. 92, 499-503

Palmquist D.L., 1984. Use of fats in diets for lactating dairy cows. In: J. Wiseman (Editor). Fats in Animal Nutrition. Butterworths, London (UK), pp. 357-381

SAS, 1990. SAS/STAT Users Guide (Release 6.03). SAS Institute Inc., Cary, NC

Stensig T. Weisbjerg M.R.. Hvelplund T., 1994. Estimation of ruminal digestibility of NDF from in sacco degradation and rumen fractional out1low rate. Acta Agr. Scand. 44. 96-109

Tackett V.L., Bertrand T.C., Jenkins T.C., Pardue F.E., Grimes L.W., 1996. Interaction of dietary fat and acid detergent fiber diets of lactating dairy cows. J. Dairy Sci. 70, 270-275

Weigel D.J., Elliott J.P., Clark J.H., 1997. Effects of amount and ruminal degradability of protein on nutrient digestibility and production by cows fed tallow. J. Dairy Sci. 80, 1150-1159

\section{STRESZCZENIE}

\section{Wplyw dodatku tluszczu i rodzaju skarmianej diety na efektywną degradację celulozy w żwaczu owiec}

Przeprowadzono sześć doświadczeń na cztcrech trykach z trwałymi kaniulami żwaczowymi, w których testowano wpływ rodzaju diety składającej się z siana $(100 \%)$ bądź siana i mieszanki treściwej (40:60\%) oraz dodanego tłuszczu w postaci oleju rzepakowego (doświadczenie I i II), oleju lnianego (doświadczenie III i IV), lub łoju (doświadczenie V i VI), w ilości 0, 4, 8 lub 10\% w suchej masie, na efektywną degradacje (ED) celulozy w żwaczu owiec. Otrzymane wyniki wskazują, że rodzaj skarmianej dicty oraz dodanego tłuszczu wpływają na efektywny rozkład celulozy w żwaczu. Dodatek oleju rzepakowego obniżył ED w obydwóch doświadczeniach, z tym, że w doświadczeniu, w którym podstawę diety stanowiło siano łąkowe różnice były statystycznie istotne $(P \leq 0,05)$. Podobnic, dodatek oleju lnianego do diety składającej się wyłącznie $z$ siana łąkowego obniżył ED, jednakże różnice nic były statystycznie istotne. Dodatek oleju lnianego do dawki, której podstawę stanowiła mieszanka treściwa zwiçkszył natomiast istotnie ( $\mathrm{P} \leq 0,05) \mathrm{ED}$ $w$ grupie drugicj $\mathrm{i}$ trzeciej. W przeprowadzonych doświadczeniach nie stwierdzono wpływu dodatku łoju na efektywną degradację celulozy w żwaczu owiec. 